\title{
ESTOQUE DE CARBONO EM ÁREA DE CANA-DE-ACÚCAR UTILIZANDO DIFERENTES PLANTAS DE COBERTURA E SISTEMAS DE PREPARO DO SOLO
}

\author{
João G. Teixeira*, Euriana M. Guimarães, Camila V. V. Farhate, Zigomar M. Souza
}

\section{Resumo}

A matéria orgânica do solo é um componente fundamental para a manutenção da capacidade produtiva dos solos. Dessa maneira, o objetivo deste estudo foi avaliar o estoque de carbono do solo influenciado por diferentes plantas de cobertura (amendoim, crotalária, milheto e sorgo) e preparos de solo (preparo convencional, preparo profundo, plantio direto e cultivo mínimo) voltado para o cenário produtivo de cana-de-açúcar.

\section{Palavras-chave: Degradação do solo, matéria orgânica do solo, sistema de manejo conservacionista.}

\section{Introdução}

A cana-de-açúcar corresponde a uma das principais culturas do Brasil e, cada vez mais, vem se estabelecendo como uma das principais fontes econômicas do país, principalmente na região sudeste. Contudo, apesar da grande demanda existente, a indústria não tem obtido uma produtividade de cana-deaçúcar satisfatória, pois o cultivo intensivo de cana-deaçúcar caraterizado por monocultivo, intenso revolvimento do solo e tráfego de máquinas tem ocasionado acelerado processo de degradação do solo.

Levando em consideração a importância da matéria orgânica na manutenção da capacidade produtiva dos solos, o objetivo desse estudo foi avaliar o estoque de carbono (C) do solo influenciado por diferentes plantas de cobertura (amendoim, crotalária, milheto e sorgo) e preparos de solo (preparo convencional, preparo profundo, plantio direto e cultivo mínimo) voltado para o cenário produtivo de cana-deaçúcar.

\section{Resultados e Discussão}

De modo geral, foram observados menores valores para o estoque de carbono em superfície e maiores em subsuperfície, o qual esteve mais relacionado à densidade do solo e a profundidade da camada, do que propriamente aos teores de carbono orgânico (Figura 1).

Considerando o efeito do manejo na camada de solo de 0,00-0,05 e 0,05-0,10 m (camadas mais influenciadas pelo sistema de manejo), verifica-se que na área em que foi utilizado o sorgo como planta de cobertura, houve maior estoque de carbono por meio da utilização do sistema de preparo profundo. Provavelmente o maior incremento de resíduos vegetais, proporcionado pelo sorgo forrageiro $\left(21 \mathrm{t} \mathrm{ha}^{-1}\right)$, contrabalanceou a maior perda de carbono proporcionado pelo sistema de preparo profundo, favorecendo um balanço positivo de $\mathrm{C}$ no solo.

Adicionalmente, para utilização da crotalária, amendoim e milheto, a associação de sistemas de preparo do solo com menor revolvimento, tais como o cultivo mínimo e o plantio direto, proporcionou maior acúmulo de carbono no solo nas camadas superficiais.

Em adição, para a maioria dos cenários (planta de cobertura e sistema de preparo do solo), o tratamento testemunha, apresentou os menores estoques de $\mathrm{C}$ nas camadas superficiais. Segundo Costa $^{1}$ e Pinheiro ${ }^{2}$, os menores teores e estoques de $\mathrm{C}$, em preparo convencional, estão associados à incorporação dos resíduos ao solo na camada arável, durante o preparo, que promove maior aeração, aumento da temperatura na camada revolvida, ruptura dos agregados e consequente exposição da matéria orgânica do solo à ação de microrganismos.
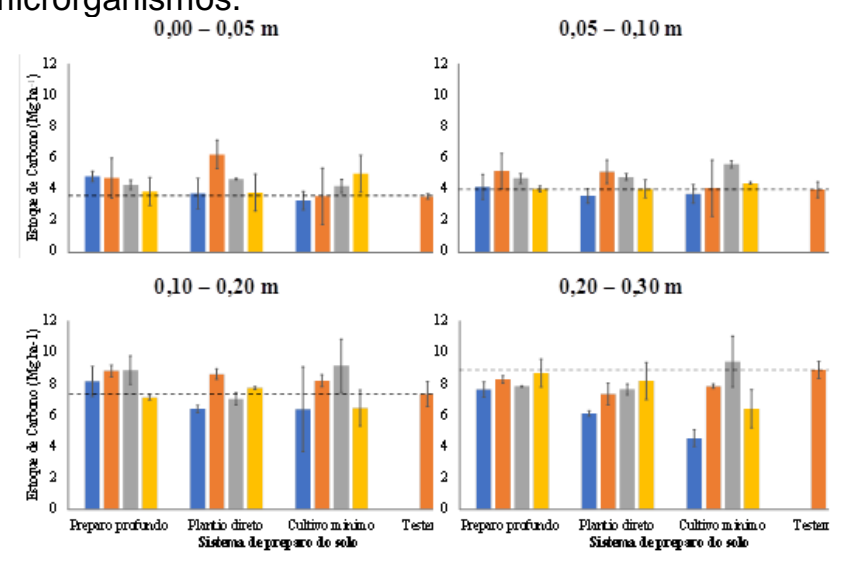

$0,30-0,70 \mathrm{~m}$

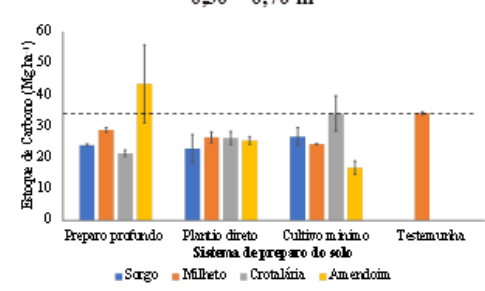

Figura 1. Estoque de carbono (C), na área experimental com diferentes plantas de cobertura avaliadas e sistemas de preparo do solo avaliados.

\section{Conclusões}

Para cada planta de cobertura há necessidade de que seja empregado um sistema de manejo específico, a fim de manter ou mesmo aumentar os estoques de carbono do solo. Para o sorgo o sistema de preparo profundo é mais adequando e, para crotalária, amendoim e milheto, sistemas de preparo conservacionistas, tais como o plantio direto e cultivo mínimo apresentou melhor desempenho.

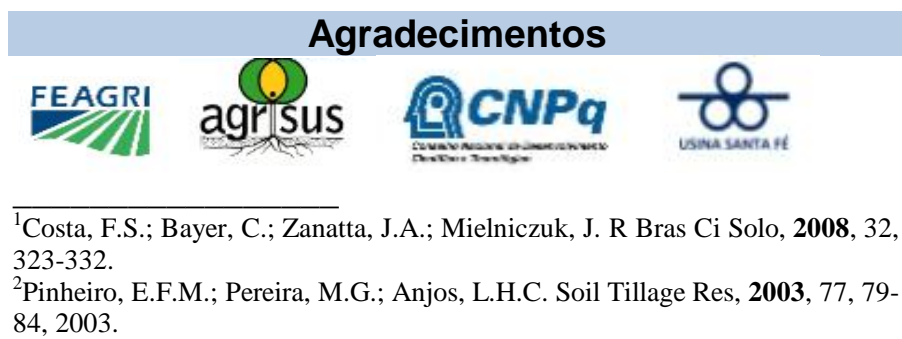

